\title{
REVISITANDO O CONCEITO DE CIDADANIA: NOTAS PARA UMA EDUCAÇÃO POLITÉCNICA
}

REVIEWING THE CITIZENSHIP CONCEPT: NOTES FOR A POLYTECHNIC EDUCATION

\author{
Adriana Geisler 1
}

Resumo A contrapelo de um projeto de sociedade e de escola que vem negando cidadania efetiva a um amplo contingente de jovens e trabalhadores no Brasil, a concepção politécnica surge como parte de um projeto emancipador que se distancia da ideologia liberal e de seus reflexos no campo do trabalho e da educação. Ao recolocar a questão do significado da cidadania hoje, este texto tem como objetivo identificar a que conceito de cidadania a noção de politecnia se filia, considerando o campo das práticas educativas e suas interfaces com a atual configuração do mundo do trabalho.

Palavras-chave politecnia; cidadania; pertencimento; singularidade.

Abstract In opposition to a community and school project which have been denying the effective citizenship to a great contingent of youth and Brazilian workers, the polytechnic conception emerges as a part of an emancipating project which is far from the liberal ideology and from its reflexes on the education and work fields. Retaking the issue of the citizenship meaning nowadays, this text aims to identify to which citizenship concept the polytechnic conception belongs, considering the educational practices field and its connection to the current aspect of the world of work.

Key words polytechnic; citizenship, belonging, singularity. 


\section{Introdução}

Ainda nos bancos escolares, aprendemos a reconhecer como implícitos na idéia de cidadania os valores da igualdade, da liberdade e da fraternidade. Segundo a melhor compreensão jurídico-legal, o cidadão é portador de um conjunto de direitos definidos na Constituição e nas leis.

A cidadania, todavia, não é unicamente um conceito jurídico-legal, mas um fenômeno histórico-social. Conceituar cidadania hoje implica, portanto, reconhecer que o próprio conceito está em disputa, dadas as contradições do capitalismo em dar continuidade ao processo civilizatório de universalização dos direitos do homem. Essa contradição se expressa, por exemplo, nas atuais mudanças no mundo do trabalho, onde o mercado, cada vez mais incapaz de absorver o chamado exército industrial de reserva, reforça o desemprego estrutural.

De acordo com Gohn (1995), podemos distinguir dois tipos de cidadania: a cidadania individual e a cidadania coletiva. Quando a cidadania mantém seu caráter universal, buscando a extensão de direitos e deveres a todas as camadas da população, estamos diante de sua expressão coletiva. Todavia, frente aos limites que as noções de igualdade e liberdade adquirem na concepção liberal burguesa, a noção e a prática da cidadania vêmse distinguindo em sua contradição característica: referir-se ao universal e voltar-se para o particular. Nesse contexto, em geral é a cidadania individual que se ergue como pretexto para atender ainda mais à necessidade de exploração do capital, constituindo-se como um conceito formal vinculado à idéia de propriedade.

A ambigüidade característica da noção liberal de cidadania revela-se com extrema nitidez no Brasil, como parte da semiperiferia do sistema capitalista global. Erguida por meio de um longo processo de colonização e mantida sob a égide de uma modernização conservadora, nossa constituição histórica excludente vai-se perpetuando às custas de uma democracia restrita, e através das alianças de interesses que a classe burguesa vem implementando nos denominados períodos de transformismo². Para Carvalho (1997), marcada pelo centralismo político e definida no espaço institucional de um Estado patrimonialista e paternalista, a cidadania brasileira revelará cidadãos de primeira, segunda e terceira classe.

No âmbito educacional, a escola brasileira, fabricada dentro de relações capitalistas, reflete e reproduz, simultaneamente, o percurso estrutural de desigualdade social que vem negando cidadania efetiva a um amplo contingente de jovens no país. O chamado dualismo da educação expressa-se na diferenciação entre o ensino que, aligeirado e profissionalizante, é reservado aos filhos das classes trabalhadoras, e a formação para o trabalho intelectual destinado às elites dirigentes (Frigotto, 2001; Ramos, 2005). 
Contraposta a essa lógica que busca corresponder às supostas necessidades do mercado e se conformar ao ideário pedagógico do capital, a concepção de politecnia busca unificar formação geral e educação profissional. Nessa perspectiva, a atividade laborativa inscreve-se como um princípio educativo geral que, ao pretender superar a dicotomia trabalho manual versus trabalho intelectual, passa a exigir a compreensão dos fundamentos científicos relativos às técnicas que apóiam o processo de trabalho no mundo moderno (Saviani, 2003).

Considerando que a relação entre educação e trabalho também tem sido objeto das lutas hegemônicas que acontecem no interior do Estado, qual o papel deste ente, no contexto mundial e brasileiro, no tocante à promoção da cidadania? Cabe afirmar a importância do Estado como mediador nas trocas entre os diferentes segmentos sociais, na perspectiva de efetivar um tipo de cidadania onde os direitos ampliam-se, mantendo a dimensão universal do conceito. O trabalho avança, no entanto, destacando que, no atual estágio do capitalismo monopolista, a configuração do Estado - e, portanto, dos direitos de cidadania no campo das políticas públicas - assume feições complexas. Nessa perspectiva, o exercício da cidadania configura direitos que dependem do investimento e da estratégia adotada por aqueles que têm pouco poder. No terreno da cidadania individual, assiste-se à fabricação da subjetividade capitalística (Guattari e Rolnik, 1999). Reassumido seu significado coletivo, ou seja, associada ao pertencimento de uma individualidade à comunidade política, a cidadania passa a ser entendida como um complexo fenômeno psicossocial, vinculado à emergência de singularidades desejantes.

Em síntese, intrinsecamente relacionada à sua construção no regime democrático burguês, a história do conceito de cidadania revela-se a partir da luta pela aquisição de um certo conjunto de direitos e dos interesses em jogo no cenário capitalista. Mais do que lutar pelo cumprimento dos direitos sociais, inclusive no campo da saúde e da educação, é necessário rediscutir a noção de cidadania. Com o objetivo de identificar a que conceito de cidadania filia-se a concepção de politecnia, recolocaremos a questão do significado da cidadania hoje, considerando o campo das práticas educativas e suas interfaces com a atual configuração do mundo do trabalho.

\section{Contextualização histórica do conceito liberal de cidadania: influências na conformação da cidadania brasileira}

A história do conceito de cidadania está intrinsecamente relacionada à sua construção no regime democrático burguês. É digno de nota que já na pólis grega, onde os homens livres debatiam e se responsabilizavam jurídica e administrativamente pelos rumos dos negócios públicos, a cidadania, como 
exercício da política, era uma contraposição direta à 'violência urbana'. Embora restrita, pois excluía mulheres, crianças e escravos, a democracia direta - particularmente em Atenas - fora capaz de promover certo exercício de direitos e deveres na esfera pública, constituindo-se, portanto, como um processo civilizatório.

No alvorecer da sociedade capitalista, o exercício da cidadania, após o longo período feudal, adquire relevância social. A cidadania expressa-se na forma de direitos civis diretamente relacionados à instituição de relações sociais mercantilistas. A centralidade da noção de cidadania estava no reconhecimento do direito dos antigos servos disporem do corpo, inclusive da liberdade de locomoção.

Contraposto ao Estado imobilista característico da sociedade aristocrático-feudal, o emergente Estado liberal traduzia uma concepção de mundo que destronou o antigo direito obtido pelo nascimento. Atrelada ao seu caráter revolucionário de então e mobilizando todos os setores espoliados em prol do desenvolvimento das cidades, a contestação burguesa incluía em sua pauta de reivindicações a visão de que todos os homens nascem livres e são, por natureza, igualmente portadores de direitos. Esse processo culminará na Revolução Francesa: o capitalismo liberal, assim, estrutura-se sobre a noção de direito político.

A burguesia como classe revolucionária relaciona-se, portanto, com surgimento da noção de indivíduo e com a incorporação desta noção à criação de um Estado Democrático de Direito. Esse momento, que se traduz por liberalismo político, marca o aparecimento da primeira geração de direitos: os direitos individuais clássicos, definidos por um abster-se por parte do Estado. Sem deixar de ser necessário, mas como o fiel de uma balança, o Estado de Direito que se consolidara com as revoluções burguesas pretendia, em sua neutralidade, assegurar o bom convívio social nos novos núcleos urbanos.

Verifica-se que a igualdade e a liberdade foram postuladas como valores universais básicos e essenciais para orientar a construção da cidadania neste contexto histórico. A luta pela aquisição de determinado conjunto de direitos e dos interesses em jogo no cenário capitalista expõe, no entanto, as contradições dessa construção. A igualdade - e a própria noção de cidadania -, a partir de seu nascedouro na Revolução Francesa, torna-se essencialista, pois a proposta emancipatória da burguesia em ascensão contemplava a luta por valores universais que acabaram por se expressar, sobretudo, na esfera da liberdade individual. Conseqüentemente, como um conceito formal, a cidadania, também individual, assume seu caráter particularista na manutenção das estruturas sociais de poder e privilégio.

Se a efetivação dos chamados direitos individuais clássicos pressupôs a 'imposição' de um 'não fazer' (ou de um 'deixar de fazer') por parte do Estado, para a concretização dos chamados direitos sociais, as constituições 
modernas - em função da situação de desigualdade social resultante do modelo de desenvolvimento econômico dominante no cenário atual - exigem dos poderes públicos e da sociedade um conjunto de ações integradas no sentido da promoção de serviços que contemplem as necessidades humanas básicas.

Marshall (1988), ao estabelecer uma correlação entre cada fase do capitalismo e o surgimento gradual das gerações de direito (direitos civis, direitos políticos, direitos sociais), afirma que os direitos sociais são hoje a marca da cidadania em disputa no atual estágio monopolista. De fato, a democracia moderna é testemunha do gradual e conseqüente surgimento das gerações de direitos que a compõem. Todavia, quando o discurso corrente refere-se à garantia de direitos relacionados às necessidades humanas básicas, é confundindo-se com o grupo de direitos sociais que a cidadania formal capitalista busca sustentar-se na prática.

Encarada como o próprio direito à vida em sua plenitude, o exercício da cidadania não se deve restringir ao gozo de qualquer dos direitos pertencentes a um dos três grupos tomados isoladamente. Em suma, a configuração do Estado hoje e, portanto, dos direitos humanos no campo das políticas públicas assume feições complexas.

A história do velho continente fora testemunha de que o exercício da cidadania, ainda que em seu sentido liberal, possibilitou a afirmação do universal onde o particular mantinha o status quo e as vantagens auferidas pelo clero e pela nobreza. De acordo com DaMatta (1997), hoje, nesses países, a utilização do conceito de 'cidadania local' presta-se mais como critério distintivo entre os nacionais e os 'outros' do que como ferramenta imprescindível na extinção de privilégios. Nessas sociedades, sem afrontar bruscamente, para os nacionais, o caráter nivelador contido na concepção de cidadania, a conciliação entre a crença no mercado e a disseminação do individualismo como um valor no tecido social surge como alternativa para hierarquizar a totalidade social.

No Brasil, a noção de cidadania também vai conviver com um mecanismo de discriminação social, mas aqui, considerada negativamente, ela ganha um sentido diferente daquele que tradicionalmente lhe é conferido. O que deveria caracterizar-se pela impessoalidade (ou universalidade) acaba por se transformar num instrumento a serviço da institucionalização de prerrogativas. Não há, portanto, porque falarmos de uma única cidadania brasileira - aquela construída nos avanços da história política da Europa Ocidental.

Segundo DaMatta (2001), o Brasil atual demonstra tanto os modernos avanços na criação de um Estado Nacional baseado na igualdade e no sufrágio universal, como deixa aparente nossa vergonhosa e consistente tradição 'familista' e 'clientelista'. Para o antropólogo, nossa história inova, recuperando um 'nepotismo à brasileira' que, 'no sabe com quem está falando?', 
evidencia a arbitrariedade do sistema.

Na prática, nem todos estão sujeitos àquele tão bem formulado conjunto de normas coativamente impostas pelo Estado. Poucos são os que devem sujeitar-se ao difícil reconhecimento de seus direitos diante da burocracia estatal. Ser cidadão no Brasil é um fardo. Antes de ser a célula mater do corpo social, o cidadão, indivíduo considerado per si, não tem o mesmo prestígio que os outros membros 'bem relacionados' da comunidade.

Ainda conforme o autor, a cada eleição as antigas aristocracias se refazem. Não porque ainda estejamos numa sociedade fundada no direito divino dos reis, mas porque nossos princípios sociais autoritários possuem uma peculiar configuração relacional. Nas palavras de DaMatta (2001, p. 17), "ficamos com o amigo e damos um jeito na lei".

Perpetuamente conquistado, nosso individualismo contra legem tornouse historicamente uma resposta possível a uma tradição jurídica e política centralizadora. Diante desse modo de organização burocrático de um Estado autoritário e contaminado por uma política 'familista', respondemos com um modo de navegação social: a 'malandragem'. Na contraface do poderoso 'olha quem está falando', encontramos um modo simpático de conciliar os interesses em conflito. Se o primeiro reafirma a autoridade do solicitante e indica que, neste país, a lei não se aplica a todos, a malandragem, ao invocar elementos externos ao acontecimento, provoca o estabelecimento de uma 'relação' e uma solução harmoniosa entre as partes. Assim, o que podemos dizer do conhecido 'jeitinho brasileiro' é que:

“(...) não é só um tipo de ação concreta situada entre a lei e a plena desonestidade, mas, também, e sobretudo, é uma possibilidade de proceder socialmente, um modo tipicamente brasileiro de cumprir ordens absurdas, uma forma ou estilo de conciliar ordens impossíveis de serem cumpridas com situações específicas (...). A malandragem, assim, não é simplesmente uma singularidade inconseqüente de todos nós brasileiros. Ou uma revelação de cinismo e gosto pelo grosseiro e pelo desonesto. É muito mais que isso. De fato, trata-se mesmo de um modo - jeito ou estilo - profundamente original e brasileiro de viver, e às vezes sobreviver, num sistema em que a casa nem sempre fala com a rua e as leis formais da vida pública nada têm a ver com as boas regras de moralidade costumeira que governam a nossa honra (...)" (DaMatta, 1986, p. 103-104).

Para DaMatta (1997), o povo percebe que, no trato da coisa pública, boa parte dos seus representantes convenientemente utiliza um critério para a casa, outro para a rua; um peso para o cidadão, um afago para os amigos.

Carvalho (1987, p. 160) esclarece, ao tecer sua análise do comportamento popular na cidade do Rio de Janeiro diante do Estado republicano nascente, que, já naquela época, "o povo sabia que o formal não era sério". Enquanto 
isso, segundo o mesmo autor, eram coincidentes as opiniões dos observadores estrangeiros, dos membros da elite (até mesmo os mais progressistas) e da própria liderança do movimento operário sobre o povo brasileiro. $\mathrm{Na}$ realidade, para os dois primeiros, se a população de um modo geral apenas assistira bestializada à proclamação da República, não se podia nem afirmar, de acordo com o melhor emprego do conceito, que havia 'povo' no Brasil.

Entre as lideranças populares, essa análise era traduzida por falta de 'espírito de luta' dos trabalhadores. O que mais incomodava a vanguarda do pensamento operário na época era o que eles identificavam como uma certa tendência para a carnavalização nos eventos de mobilização da classe. Aliás, também em relação ao carnaval, os reformistas, tanto da elite quanto do operariado, mantinham-se lado a lado: "a festa revelava um povo incapaz de pensar e sentir" (Carvalho, 1987, p. 140).

Era impensável para a intelectualidade brasileira na ocasião, que, após repetidas tentativas de mobilização política da população, o citadino demonstrasse grande interesse e habilidade em eventos de natureza não política. Na virada do século XX, enquanto fracassavam as organizações baseadas nos moldes conhecidos - nos sistemas liberais -, o entrudo, o carnaval e as festas - sobretudo as religiosas - atraíam milhares de pessoas.

Para Carvalho (1987, p. 147), era nas "grandes festas que a população parecia reconhecer-se como comunidade". O assistencialismo e o cooperativismo eram a marca das associações religiosas e de auxílio mútuo que dominavam o cenário na primeira década do século XX. A ação popular visava, acima de tudo, ao estabelecimento de limites ao governo enquanto encarregado da administração dos serviços públicos a serem prestados pelo Estado. Reclamava-se mais como consumidor, do que como quem, desejoso de interferir politicamente, reivindica seus direitos e manifesta sua oposição na esfera pública. Era-se mais súdito do que cidadão; mais alvo da ação de uma entidade externa a quem se recorre do que controlador e partícipe na elaboração de políticas públicas. Conforme nos interroga Carvalho:

“Como explicar este comportamento político da população do Rio de Janeiro? De um lado, a indiferença pela participação, a ausência de visão do governo como responsabilidade coletiva, de visão da política como esfera pública de ação, como campo em que os cidadãos se podem reconhecer como coletividade, sem excluir a aceitação do papel do Estado e certa noção dos limites deste papel e de alguns direitos do cidadão. De outro, o contraste de um comportamento participativo em outras esferas de ação, como a religião, a assistência mútua e as grandes festas (...)" (Carvalho, 1987, p. 147).

O apego da população ao carnavalesco e a inexistência no Rio de Janeiro de uma comunidade política de feição liberal podem ser compreendidas se 
considerarmos que a investida liberal individualista, suficiente para impulsionar as mudanças de fim de século, não fora igualmente capaz de alcançar o necessário fundamento associativo de um típico Estado liberal democrático. Soterrados os elementos integrativos presentes no Estado monárquico de outrora, a participação e a liberdade não estavam garantidas no novo regime. Aqueles que se aproximavam do poder administrativo o faziam ou com o intuito de utilizar a máquina burocrática em proveito próprio, ou porque eram solicitados como instrumentos da desordem indispensáveis à suposta 'ordem pública'.

No início da República, diante da convivência dos próprios representantes do poder público com a desordem, a observância à lei tornara-se mera formalidade. O cotidiano estava marcado pelo império de uma legalidade não escrita. A revolta popular instalava-se apenas quando este pacto implícito abalava-se pelas raras tentativas governamentais de aplicação estrita da lei. Podemos falar nesse momento de participação política? O habitante da cidade era cidadão?

Nas palavras de Carvalho,

“Não havia caminhos de participação, a República não era para valer. (...) o bestializado era quem levasse a política a sério, era o que se prestasse à manipulação. (...) Quem apenas assistia, como fazia o povo do Rio por ocasião das grandes transformações realizadas à sua revelia, estava longe de ser bestializado. Era bilontra" (Carvalho, 1987, p. 160).

Na metrópole moderna que se configurava, os habitantes fluminenses foram criando, com humor, alternativas de auto-reconhecimento.

Também para Santos (1979), no início da história republicana verificamos um hiato nas relações do Estado com os diversos setores da população. O autor prefere situar sua análise, no entanto, no período, aproximadamente, de 1931 a 1940, correspondente ao que se pode denominar 'regulação social acelerada'.

Segundo este autor, através da regulação do processo acumulativo, a Revolução de 30 surgiu para viabilizar uma política social capaz de estimular o crescimento e, por conseguinte, garantir a manutenção de uma ordem essencialmente capitalista. Nesse sentido,

“(...) o formato, por assim dizer da engenharia institucional que presidiu a reorganização do processo acumulativo, (...) deixará raízes na ordem social brasileira com repercussões na cultura cívica do país e até mesmo nos conceitos e preconceitos das análises sociais correntes" (Santos, 1979, p. 68).

A noção basilar escolhida pelo sociólogo para o entendimento da polí- 
tica econômico-social pós-30 é a de 'cidadania regulada'. O qualitativo 'regulada' retira do conceito de cidadania seu valor político e o configura como a resultante de um sistema de estratificação ocupacional estipulado por norma legal. Em outros termos, para ser cidadão não bastava ter reconhecido seus valores como membro da comunidade; cidadãos eram todos aqueles que integravam o processo de produção através de uma das profissões regulamentadas em lei e, como tal, possuíam os direitos concernentes ao lugar ocupado nesse processo.

Criada em 1932, a carteira de trabalho configurava-se como necessário instrumento de comprovação jurídica para o gozo desses direitos trabalhistas. Nessa 'certidão de nascimento cívico', firmava-se o acordo entre o Estado e a cidadania regulada.

A aliança entre cidadania e ocupação que se deu nesse momento preparou o terreno institucional para a subseqüente ampliação nos conceitos de marginalidade e mercado informal de trabalho. Dessas categorias, como pré-cidadãos, passaram a fazer parte não somente os desempregados, mas os subempregados e trabalhadores cujos ofícios ainda não haviam sido definidos legalmente.

Já o empregado poderia (e deveria), regularizada a sua ocupação, associar-se a um sindicato reconhecido pelo Estado, 'sob pena' de 'excluir-se' das convenções coletivas de trabalho. A regulamentação das profissões, a carteira profissional e o sindicato público vão conformar o tripé a partir do qual a cidadania passa a ser entendida.

Longe de se configurar como categoria estratégica na ampliação de direitos a todos os setores da população, a cidadania nessa época representou, para benefício da elite burocrática que compunha os sindicatos da época, a consolidação da 'indústria de favores' em nosso país. Para o contingente de assalariados em profissões regulamentadas, que possuíam carteira assinada e eram devidamente sindicalizados, cabia a ilusão de uma compensação paternalista que, sobretudo nos momentos reivindicatórios desses trabalhadores, mostrava sua face opressiva. A todos aqueles que legalmente não tomavam parte do processo produtivo, a cidadania era negada. Nesse período histórico, assistimos ao Estado brasileiro paternalista e repressivo distanciar-se ainda mais da igualdade e da tolerância que caracterizam um Estado providente.

Wacquant (2001) destaca que o contexto de redução de mercado de trabalho torna-se ainda mais desumano à medida que se faz acompanhar tanto da falta de políticas estatais (configurando o abandono urbano) como dos aparatos repressivos da polícia e do sistema penal. No momento em que se recoloca em cartaz o antigo filme do mercado auto-regulamentado, substitui-se a participação efetiva do Estado econômico e social pela onipresença ostensiva do Estado policial e penitenciário. A vivência gradual que construiu a democracia liberal e resgatou a experiência da cidadania 
no seio do capitalismo europeu parece ter-nos deixado o legado de um lugar subalterno no processo capitalista. Nesse sentido, inscrita no processo de lutas pela apropriação do espaço social, nossa história oficial tem marcado violentamente os corpos daqueles que pretende excluir.

\section{Cidadania e laço social: individualismo ou singularidade}

De acordo com DaMatta (1986, p. 66), "se a cidadania tem uma história, ela é um papel social". O autor destaca a importância de estudar a noção de cidadania (e o individualismo que ela comporta) como referencial crítico da sociedade ocidental. Seguindo os passos de Louis Dumont, DaMatta situa a civilização ocidental em oposição a um sistema de organização onde o todo predomina sobre as partes e a hierarquia é um princípio regulador da vida social.

De fato, nos primórdios da Era Moderna, a grande tentativa do ser humano fora a de superar a rotina de um viver sacramental e marcado pela imobilidade social. Tratava-se do movimento daqueles que, na Idade Média, desejavam, segundo Nunes e Pereira (1996, p. 44), ultrapassar sua condição caracterizada pela 'repetição'. A existência na Terra não podia mais ser concebida como preparação para a vida no céu.

O paradigma emergente nos séculos XVI e XVII ergueu-se, portanto, em torno de um projeto revolucionário que aglutinava de burgueses a camponeses e tinha como principais objetivos a emancipação do homem e da sociedade e a regulação da vida social. Rompendo com o Universo e com as remotas formas de convivência, o antigo servo de Deus inaugurou uma nova postura diante do mundo físico e se permitiu conhecer a si mesmo. Separado da natureza, o novo homem pretendia forjar sua identidade.

Para DaMatta (1986), como berço da 'revolução individualista', a civilização ocidental, por um lado, foi responsável pelo entendimento de que a sociedade serve à satisfação do indivíduo e, por outro, deu ao mesmo indivíduo a possibilidade de reconhecer-se como pertencente a um universo fundamentalmente público.

Um universo, segundo Bauman (1997), público e institucionalizado em uma ordem artificialmente planejada, ou seja, gerada pela experiência de distanciamento entre o eu e o outro (ameaçador). Onde costumes e tradições foram substituídos pelo Estado mediador como poder legislativo exclusivo, o cidadão-indivíduo, núcleo do sistema, despojou-se dos elementos integrantes dos papéis sociais tradicionais e demarcadores de seu status social para assumir-se como entidade universal portadora de direitos e deveres perante a sociedade. Diante dessa entidade também geral e abstrata, ele dialoga com outros cidadãos sem que possa incorporar nenhuma outra identidade social. 
Resguarda-se aí, através dessa dimensão totalizadora e normativa do ideário de cidadania, a perspectiva igualitária pretendida dentro da dinâmica social.

Assim, desde a formação dos Estados modernos, reorganizado o espaço social, o indivíduo foi declarado livre de todas as obrigações para com os seres humanos - exceto as reguladas por lei. Todas as relações entre o indivíduo e a sociedade passaram a ser intermediadas pelas instituições sociais. Encarregadas de preservar, proteger e defender os interesses dos indivíduos, não raro tais instituições acabam por sustentar um discurso social de exclusão da responsabilidade construída no relacionamento.

A incerteza moral e a inadequação da afeição provocada pela presença do outro constituem a lógica que sustenta esse discurso. Como legado da Revolução Francesa, "ninguém é obrigado a fazer ou deixar de fazer alguma coisa, senão em virtude de lei", mas "ser um trabalhador livre, ser um selfmade man significou perder um sistema de grande certeza social, apesar de opressivo" (Zamora, 2003, p. 1).

Pretensamente emancipado, o ser da razão chamou para si a tarefa de construir sua história, interesse que tomou corpo na proposta iluminista fundada numa lógica conceitual e científica de pensamento, num tempo linear e sempre a posteriori, e na comprobabilidade como requisito de verdade. Coube ao novo método da ciência buscar primeiro o domínio sobre a natureza, depois, já no século XIX, o controle do homem e da sociedade. No cenário político, garantida a hegemonia da burguesia, o objetivo regulador se impôs sobre o emancipatório, e o empreendimento científico de descoberta da 'essência humana' foi orientado pela solidificação da aliança entre o paradigma moderno e o capitalismo.

Nunes e Pereira (1996) destacam que, na modernidade, o sujeito trazido (e que se trouxe) à luz pela palavra pagou o preço da alienação de seu próprio nome. De acordo com Milner (s.d, p. 225), “a ciência se constitui pela exclusão do desejo para fora do seu campo (...) e se desenrola num mundo aonde a verdade só pode falar do lado das coisas". O 'senhor' instrumentalizado por uma ciência pretensamente neutra tornou-se escravo de suas próprias fórmulas.

Desvinculada a vida da experiência, tudo que é humano começa a ser percebido com estranheza. Tempos modernos ou falta de tempo? Surge o mal-estar: o homem precisa estar sempre à frente de seu próprio tempo.

Segundo Kierkegaard, é possível descrever o período moderno como:

“(...) o tempo do isolamento e da atomização: os seres humanos se relacionam uns com os outros como meras cifras e indivíduos isolados. Ao criarem associações e organizações, eles não negam, nem superam, de modo algum, essa atomização. Grandes ou pequenas, essas associações reúnem números e não sujeitos vivos e concretos" (Kierkegaard apud Kosik, 1995, p. 6). 
Em suma, encarregado de tornar o presente sem nexo, o progresso perseguido pela modernidade conduziu tanto à irresponsabilidade em relação a si quanto à indiferença em relação ao outro (Costa, 2000).

Costa (1994) ressalta a brusca mudança no sentido do valor da vida hoje. O autor salienta que nem as virtudes públicas nem as privadas são cultuadas pelos indivíduos. Segundo ele, vivemos na ideologia do bem-estar, onde o que tem valor não é a virtude, mas aquilo que pode ser contabilizado por seu potencial de lucro, ou seja, o sucesso. Para o psicanalista, antes éramos felizes ou infelizes, bons ou maus, mas à medida que deixamos de lidar com a contingência do desejo do outro, tornamo-nos obsoletos, imprestáveis, inutilizáveis ou, ao contrário, algo que tem liqüidez.

Kosik (1995) afirma que o século XX trata de afastar o trágico, reduzindo a vida humana à causalidade. Apesar da crença de que estamos mergulhados na tragédia, estamos, na realidade, defrontando-nos com desastres que permitem serem reduzidos a suas causas técnicas. Essa visão de mundo que minimiza tudo à banalidade é fruto de um poder que, no seu íntimo, não reconhece heróis. O olhar dos lacaios impele à morte do outro pouca significação.

Podemos dizer que a 'alma do lacaio' evidenciada por Kosik corresponde à dos 'amoladores de facas' descritos por Baptista (1999). De acordo com este último, a violência também encarna-se no cotidiano do brasileiro travestida de miséria. Assumindo suas mais variadas formas ('miséria do pobre', 'miséria da diferença' etc.), ela tem como aliados determinados modos de viver e discursos que se difundem em nossa sociedade, privando a vida da experiência, da criação coletiva e da luta política. Engana-se quem atribui apenas aos atos homicidas a qualidade de violentos.

Para Baptista, os 'amoladores de facas', os supostos baluartes da razão, da modernidade, do humanismo, contribuem indiretamente na fabricação de vítimas e no incentivo disfarçado ao ato genocida. A sociedade é afetada por suas constantes formulações enriquecidas por um discurso aparentemente individual e desligado de sua implicação coletiva e de sua dimensão histórica, sociopolítica e de relação com o poder.

Numa operação de exclusão para evitar o trágico, nossa época parece ocupar-se com a institucionalização do grotesco, haja vista que, na contemporaneidade, o narcisismo tem-se intensificado e se apresentado de maneira bastante peculiar. Se o 'delinqüente arrogante' perde a noção de interdito e mergulha na cultura regida pelo cinismo, encontramos em sua contraface o 'burocrata servil' que, rotineiramente, volta-se para o desejo de obedecer e anula-se a si mesmo (Castelo, 1994). O paradigma ético que observamos em nosso mundo contemporâneo expressa-se pelo vazio de sentidos, de premissas e de valores, pela ausência de ideologias e pelo individualismo narcíseo e hedonista que corrói a estrutura social (Bauman, 1997). 
De acordo com Sousa Santos (1999), vivemos um tempo de 'horror econômico', onde as chamadas 'crise de regulação' e 'crise de emancipação' nutrem-se mutuamente. Nesse contexto, a cegueira social é alimentada pela mídia que se compraz com a realidade virtual. Ainda segundo o autor, se as angústias de outrora provocavam indignação, hoje precisamos nos perguntar se a subjetividade contemporânea está sendo construída sobre as bases de um autoritarismo crescente do pensamento único.

Numa sociedade como a brasileira, alvo das políticas neoliberais, um sistema universal de valores sucumbe a inúmeras formas de apartheid ${ }^{3}$. Aqui, parece plenamente possível a manutenção de instituições que, embora se digam 'democráticas', foram criadas para preservar uma igualdade que sabemos hoje ser formal. É nesse momento que o Estado deixa de ser o regulador e torna-se incapaz de fazer políticas sociais. A democracia perde seu potencial distributivo e, assim esvaziada, torna-se compatível com o liberalismo. Conforme Eco (apud Vilhena et al., 2001, p. 8), “é preciso legislar de novo... A dimensão ética começa quando entra em cena o outro".

A necessidade da afirmação de um renovado paradigma ético é trazida para o centro das discussões a partir do entendimento de que o estado de justiça social somente pode ser garantido pelo reconhecimento de que é com o outro que eu me constituo.

Essa inversão tem como base a aceitação da alteridade como valor positivo, pois conforme nos falam Vilhena et al. (2001, p. 145), “o outro não é uma reprodução imperfeita do eu".

Dentro do que se pode denominar 'ética das virtudes públicas', o investimento alteritário é condição para que o sujeito não se apresente como portador daquela universidade definida pelo alheamento em relação ao outro e pela irresponsabilidade em relação a si. Impõe-se a pergunta: o processo de subjetivação é oposto à socialização ou o sujeito constitui-se ingressando na cultura?

A despeito da aderência do mundo moderno à expansão narcísica que nega o vínculo social com o outro, Enriquez (1990, p. 13) procura escapar do que denomina "oposição maniqueísta entre sociedade repressiva e desejo individual libertador". Sem desconsiderar a dificuldade que os indivíduos encontram para se tornarem atores sociais, o autor destaca as relações existentes entre o percurso individual e a trajetória da sociedade. Segundo ele, o que marca a humanidade do homem é sua singular condição de ser pulsional e social. O pulsional, ao imprimir ao organismo um movimento que visa ao outro, faz parte do fundamento de cada sujeito e do alicerce da vida social.

Como veremos, nos vínculos que promove do mundo interno com o externo, o desejo é o que possibilita a expressão da subjetividade como uma vivência criativa de reconhecimento do outro como constitutivo do próprio 
eu e do mundo ao qual se pertence (Coelho Junior, s.d.). Da mesma forma, reconhecer o outro como ultrapassagem de nossa perspectiva narcisista é tecer, nas palavras de Sousa Santos (2002, p. 37), um "paradigma prudente para uma vida decente".

Em síntese, esse percurso de elaboração é complexo, envolvendo tanto afeto quando reflexão, tanto sensibilidade quanto razão - ambos vivenciados numa práxis libertadora. No dizer de Sawaia (1996, p. 164), “conhecimento, ação e afetividade são elementos de um mesmo processo, o de orientar a relação do homem com o mundo e com o outro".

Portanto, se, como mencionamos, a cidadania não é somente um fenômeno jurídico-legal, ela tampouco é um fenômeno unicamente social. Compreender as interações entre o eu e o outro, entre o indivíduo e a sociedade, é entrar no terreno das discussões sobre cidadania como complexo fenômeno psicossocial.

\section{Cidadania como pertencimento}

Vimos que, encarado como o próprio direito à vida em sua plenitude, o direito de cidadania não se resume ao atendimento às necessidades humanas básicas. Ao invés de mero receptor, o cidadão deve ser realmente sujeito dos direitos que pretende conquistar.

Paradoxalmente, com DaMatta (1997), suposta a fragilidade do cidadão brasileiro diante da falta de reconhecimento social, também observamos que no Brasil não há porque falarmos de uma única cidadania - aquela construída nos avanços da história política da Europa Ocidental. Em nosso 'cenário de ausências', esse autor percebe o que denomina "indivíduo sem rosto". Assim,

“É impossível cobrar democracia dos nossos companheiros que moram na periferia de São Paulo, nas favelas do Rio de Janeiro, nos alagados de Salvador e de Recife quando eles vêem os heróis das novelas. São todos bandidos! E depois as pessoas querem que quem more na periferia - gente relativamente analfabeta, que não tem escolaridade, não tem educação, muito menos educação política, porque não pode ler, não sabe e não pode ler, não foi treinada, não tem capacidade de fazer a crítica ao que está assistindo - querem que essas pessoas obedeçam aos sinais de trânsito, para começar" (DaMatta,1997, p. 28-29).

O reconhecimento de um Estado onipotente, ora autoritário, ora paternalista, não nos impede de buscar entender se o cidadão brasileiro também pode ser portador de uma consciência cívica diferente da apontada por DaMatta. Se nos constituímos como corpo social na base da 'malandragem', 
podemos encontrar, respeitadas as nossas peculiaridades, outras formas do fazer-se cidadão?

Se a possibilidade de cidadania plena só se concretiza se o direito de reivindicar direitos estiver assegurado, em nosso país, para que esta condição possa ser satisfeita, a apropriação de espaços precisa ser continuamente uma prática encaminhada de forma coletiva. Nas metrópoles brasileiras, esse 'a-poderar-se' como requisito indispensável no caminho de construção de leis favoráveis à extensão da cidadania equivale à reedificação de uma apropriação histórica.

Dentro dessa perspectiva de que a cidadania não pode ser pensada apenas em termos de direitos a receber, a lei, mesmo em sua ambigüidade, pode ser também ferramenta para fazer valer os direitos da maioria da população. Embora saibamos que a luta pela cidadania não se restringe às leis, estas lhe são essenciais. A fim de favorecer a ampliação da cidadania é imperioso que aprendamos a delas fazer uso e, sobretudo, que ajudemos a elaborá-las. Nessa perspectiva,

“O Direito, enquanto forma, não existe somente no cérebro e nas teorias dos juristas especializados; ele tem uma história real, paralela, que não se desenvolve como um sistema conceitual, mas como um particular sistema de relações" (PashuKanis apud Lyra Filho, p. 101).

Lapassade (1989) indica que as mediações institucionais penetram em toda sociedade. Se o Estado, por vezes, coloca-se como guardião do instituído, e a instituição é a norma geral de comportamento, como grupo instituímos o tempo inteiro. Conforme ressalta Guirado (1987), não há entre os níveis de realidade social sobre-relação, mas sim, inter-relação. Numa crítica às noções estanques de super e infra-estrutura, a autora desloca o lugar da burocracia para a política. O 'inimigo público número um' deixa de ser o corpo administrativo estatal, para tornar-se tudo aquilo que impede a construção coletiva e o esforço instituinte de um novo sistema institucional.

Foucault (1992) nos lembra que o poder deve ser analisado como algo que circula, que funciona em cadeia. Em outros termos, nas malhas do poder os indivíduos estão tanto em posição de sofrer sua ação como de exercê-lo. Para o autor, o poder não somente se aplica aos indivíduos, mas também passa por eles.

Na medida em que declaramos a ineficácia de um entendimento pautado exclusivamente nas chamadas determinações estruturais, os processos de produção de subjetividades não podem ser dispensados. De acordo com Guattari (1992), nas disputas travadas no tecido social, não existe, a princípio, uma oposição entre o que refere a macropolítica ou a micropolítica - repousando esta última sobre a formação do desejo no campo social. 
Verificamos que a solidificação da aliança entre o paradigma moderno e o capitalismo favoreceu, em sua busca desenfreada pelo progresso e pelo consumo, a produção de subjetividades voltadas a uma concepção extremamente individualista de vida, onde, como num jogo de espelhos, ora a arrogância, ora o desejo de obedecer faz morada. A partir da decadência de um tipo de organização social mais comunitária, a estrutura da sociedade passou a conviver de forma mais estreita com a tendência de se considerar como finalidade da vida a fruição do prazer individual e imediato. Essa descrição corresponde ao que Guattari e Rolnik (1999) vão denunciar como sendo a instauração de processos de individualização fundamentais à produção dominante da subjetividade capitalística.

Para estes autores, a produção de subjetividades não está aprioristicamente vinculada ao que concebemos como individual, nem ao social. A subjetividade é fabricada pelo sistema capitalista, não apenas na dependência das estruturas pesadas de produção. Diferentes instâncias, extra e intrapsíquicas, são postas em conexão no registro do social, e o indivíduo, como consumidor final da subjetividade que circula nos conjuntos sociais, tanto pode submeter-se aos componentes dessa subjetividade tal como ele a recebe ('processo de individuação'), quanto vivê-la de maneira criativa em sua existência particular ('processo de singularização').

Nessa fabricação, o desejo de submissão intervém, estimulando o indivíduo a agir como simples receptor da subjetividade em circulação nos espaços sociais. Na emergência dos chamados processos de singularização, é também o desejo, mas o de uma vivência criativa, que se enuncia, motivando os indivíduos a agirem em prol da ampliação da cidadania. O desejo - fluxo da vida - participa, assim, do estabelecimento de relações que auxiliam o homem e a mulher da contemporaneidade na construção de um projeto identificado com o exercício da cidadania em sua plenitude.

Busca-se dentro de si uma sensação de poder que, da maneira como é experimentada, afasta-se dos elementos provenientes da cultura do narcisismo retratada por inúmeros autores, dentre eles Costa (1994 e 2000) e Bauman (1997). As condições para a emergência dessa forma singular de ser dependem de um ambiente social promotor de uma concepção coletiva de cidadania: a 'cidadania como pertencimento'. É nesse espaço que as relações personalíssimas, características dessa nossa cultura que exalta o mesmo, podem perder importância diante da procura por soluções políticas que, no debate público, ressaltam as diferenças. A singularidade emerge justamente no estabelecimento da diferença entre o eu e o outro.

Tratando o conceito de cidadania a partir de seu sentido mais amplo coletivo e emancipatório -, encontramos nos movimentos sociais que visam à redução das desigualdades entre as diferentes classes sociais um exemplo dessa virtude cívica não registrada por DaMatta. 
Diferentemente das alternativas de auto-reconhecimento encontradas no nascedouro do Estado republicano, ou do refúgio populista concebido no ventre de uma cidadania regulada, o período entre as greves do $\mathrm{ABC}$ e a escolha de Tancredo Neves pelo Colégio Eleitoral, de 1978 a 1985, ficaram registrados nos anais da política brasileira como um momento de transição marcado por transformações significativas no conjunto da sociedade civil. Componentes dos mais variados grupos populares retornam, de maneira organizada, à cena pública, provocando, acima de tudo, a sua própria visibilidade.

A convergência dos pequenos movimentos inicia sua trajetória contestando a ordem social vigente, mas a isso não se limita. Não se estava apenas diante de um momento de ruptura, no qual os mecanismos estruturais fundamentais à repetição da ordem, ao se alterarem por eles mesmos, proporcionariam, no deslizar dos padrões de legitimação para os de contestação, alguma transformação social.

Primeiramente traduzida como mobilização em prol do direito de reivindicar seus direitos, a atitude desses novos sujeitos provocou na intelectualidade brasileira uma nova e gradual compreensão acerca das experiências oriundas do saber e do cotidiano populares. A maneira pela qual as classes populares passaram a se expressar na arena pública sugeria a valorização de suas manifestações sociais. Agora menos reativos e mais autônomos, os movimentos sociais fizeram-se redescobrir não mais ofuscados pelas modalidades dominantes de sua representação, mas assumindo o rosto renovado de um sujeito coletivo.

No 'novo tempo', em que o Estado não era mais o único parâmetro a partir do qual se podia avaliar a relevância dos movimentos sociais, via-se a emergência de autênticas potencialidades, que se constituíam a partir de um processo de auto-organização comprometido com a memória dos vencidos e enraizado na tradição histórica não oficial. De acordo com a descrição de Sader (1988, p. 55), "uma coletividade onde se elabora uma identidade e se organizam práticas através das quais seus membros pretendem defender seus interesses e expressar suas vontades, constituindose nessas lutas".

O novo sujeito social descobre e se descobre no projeto coletivo. "O reconhecimento daquela identidade coletiva equivale ao reconhecimento de sua própria capacidade de auto-organização e de autodeterminação" (Marques Neto, 1994, p. 26).

A autonomia que se revela nesse processo é fruto da elaboração das determinações externas das quais o sujeito não é livre. As experiências reconhecidas pelo coletivo gerado servirão de guia para um esforço reflexivo que tem como matéria-prima o que o sujeito estabelece como vontade própria. A racionalidade empregada não é, no entanto, puro desdobramento 
da consciência de um ator privilegiado, mas o resultado efetivo, e também afetivo, proporcionado pelo encontro das mais diversas estratégias. Verificase a reunião entre a idéia de sujeito e a de projeto. É uma construção dupla: a da própria identidade e a de projetos que o grupo acolhe como necessários, tanto ao fortalecimento dos laços internos que motivam a resistência, quanto à indispensável transformação da sociedade como um todo.

\section{Educar o trabalhador cidadão e o ser humano emancipado}

Indissociável da sociedade, a escola brasileira reproduz o processo histórico excludente que se tem caracterizado por uma democracia restrita e pelas estruturas de poder e de classe que foram se cristalizando no Brasil.

A profunda desigualdade social que se manifesta no desequilíbrio de forças entre capital e trabalho se decompõe (e se realimenta) da desigualdade educacional expressa, comumente, na dicotomia entre o ensino com vistas à 'competência' para trabalho produtivo e o ensino que, dedicado ao trabalho intelectual, volta-se para a formação das elites dirigentes do país (Ramos, 2005).

Na conhecida comparação de Campos (2000) entre a organização de uma orquestra sinfônica e a conformação de um processo de trabalho de tipo ideal, desde Taylor, o autor se vale do filme "Ensaio de orquestra", de Fellini. A orquestra sinfônica parece ser a manifestação mais perfeita da racionalidade gerencial hegemônica. Numa demonstração de fragmentação do processo de trabalho, ou seja, de separação entre quem prescreve o trabalho e quem o executa, o envolvimento dos trabalhadores, mesmo quando convocados a dar mostras de sua destreza e agilidade, restringe-se à sua função meramente instrumental. À exceção do maestro e de um ou outro solista, a quem por vezes se confere destaque, os músicos, subordinados à autoridade imposta pela pauta e pela direção do maestro, devem renunciar em nome da produção da obra de arte alheia.

Dessa forma, se é verdade que, em virtude dos avanços tecnológicos e científicos que têm marcado o capitalismo contemporâneo, podemos distinguir profundas transformações na organização do trabalho em diversos setores, se pode dizer que nesse processo, a fabricação da subjetividade na produtividade nunca foi descartada. Se a clássica estrutura organizacional procurou adequar sua produção de subjetividades à divisão técnica do trabalho fabril, a gestão contemporânea, por seu turno, mediadora dos conflitos que se impuseram ao longo da história das relações entre capital e trabalho, utiliza-se explicitamente de técnicas subjetivas na 'objetivação' dos resultados pretendidos, ou seja, no aumento da produtividade requerida pela direção geral. Reconhecida concretamente a influência de ferramentas 
comportamentais - motivação e emoção - no desempenho produtivo, coube à nova reengenharia organizacional suavizar a racionalidade dura da administração científica, revestindo a centralização de poder característica da organização racional do trabalho com a introdução de instrumentos disciplinares muito mais sutis.

A preocupação com a qualidade do produto e a satisfação do cliente obriga a uma maior aproximação entre os níveis hierárquicos no interior das empresas. Controlar a qualidade durante o processo de trabalho torna-se fundamental. A produtividade exigida implica uma maior flexibilização na estrutura das organizações. É a partir da descentralização de suas estruturas internas que as organizações esperam alcançar uma produção mais ágil e competitiva (Médici e Silva, 1993).

Nessa lógica, para ser competitivo é preciso ser mais do que eficiente, é necessário ser eficaz. A saturação na estrutura internacional do trabalho sugere modificações na relação entre capital e trabalho. Ampliar o campo de negociação entre empregador e empregado passa a ser indispensável, no esforço para articular eficiência e responsabilidade.

Fruto das concepções forjadas no seio do fordismo e do taylorismo, a produção sustentada pela fragmentação do processo de trabalho e pela imposição de uma política salarial austera cede terreno a uma organização onde o slogan da competitividade aplica-se também entre suas próprias áreas como mais um estímulo na busca pela eficácia de resultados (Deluiz, 1993).

Mesclando autoritarismo e estímulos psicológicos, a racionalidade gerencial hegemônica possui uma gama de dispositivos que, segundo Campos (2000), "voltados para reduzir as pessoas à sua objetividade", ora utiliza métodos explícitos de dominação, ora se coloca como árbitro parcial de pretensões rivais, ora intensifica sua exploração de mecanismos emocionais. De acordo com este autor:

\footnotetext{
“A racionalidade gerencial hegemônica produz sistemas de direção que se alicerçam no aprisionamento da vontade e na expropriação das possibilidades de governar da maioria. Esses sistemas, mais do que comprar a força de trabalho, exigem que os trabalhadores renunciem a desejos e interesses, substituindo-os por objetivos, normas e objeto de trabalho alheios (estranhos) a eles" (Campos, 2000, p. 32-33).
}

Portanto, se esse movimento ideológico permanente do capitalismo na tentativa de gerir a subjetividade se deixava entrever com dificuldade nos primórdios da administração científica, na gestão contemporânea o que se procura esconder são os pressupostos objetivos sob os quais se assentam as relações materiais de produção (Gurgel, 2003). 
Nessa nova estrutura, a racionalização das empresas continua a se impor, promovendo, muitas vezes, o crescimento de relações de trabalho sem vínculo empregatício e provocando o empobrecimento nas relações trabalhistas (Deluiz, 1993).

Verifica-se que o não reconhecimento do trabalho como "objetividadesubjetividade" é uma armadilha ideológica e, em nome dela, a produção da subjetividade dos trabalhadores vem sendo orientada no sentido da servidão voluntária. Ante a propalada crença de que a criatividade pode se constituir em um entrave ao progresso dos sistemas produtivos, a participação do trabalhador é estimulada exclusivamente com vistas à acumulação, e não ao desenvolvimento de sua autonomia no processo de trabalho.

Entendendo que o trabalho considerado apenas em sua 'objetividade' ou tomado numa perspectiva 'subjetivista' revela as faces antitéticas das transformações sociais implementadas pelas mudanças na organização do trabalho no capitalismo avançado, recoloca-se a questão: o percurso individual não se coloca em oposição necessária à trajetória da sociedade? Em outros termos, o processo de subjetivação não é oposto à socialização, e o sujeito se constitui ingressando na cultura. A construção do horizonte da "ominilateralidade" (Antunes, 1995) na formação profissional, ou seja, a aposta em uma forma de trabalho que realize, em sua integralidade, o livre desenvolvimento do ser humano como ser social, não pode se furtar a apreciar essa tese.

Longe dessa 'escola interessada' (Nosella, 1992)4 que se deixa orientar pelos objetivos do mercado, a proposta da formação politécnica diz respeito ao "domínio dos fundamentos científicos das diferentes técnicas que caracterizam o processo de trabalho moderno" (Saviani, 2003, p. 140). Busca-se incorporar a dimensão reflexiva ${ }^{5}$ ao trabalho produtivo, objetivando, por parte trabalhador - autônomo -, o acesso ao produto do seu trabalho concreto, ou seja, ao tipo de valores de uso ${ }^{6}$ por ele produzido.

Novamente, a autonomia tratada aqui não é fruto da produção de uma subjetividade 'inautêntica'. Resultante da mera aquisição individual de estímulos para o exercício de uma atividade laborativa estranhada, esta subjetividade alienada tem como finalidade última a produção de mercadorias, produtos ou serviços. Na relação estabelecida entre trabalho e educação profissional, a autonomia não mais é requerida exclusivamente com vistas à acumulação e à produtividade, colocando-se como obstáculo à omnilateralidade. 'Autêntica', ela ressalta do trabalho seu potencial para operar uma dupla transformação: a) de objetos e forças da natureza em produtos; b) a plena realização das individualidades.

Esse duplo movimento permite que o trabalho seja compreendido como obra coletiva (Campos, 2000) e que o sujeito-trabalhador, emancipado - longe das armadilhas do estímulo à capacidade individual e de sua con- 
seqüente acomodação ao sistema de produção -, possa investir como autor capaz de interferir de fato nos processos decisórios relativos à co-gestão dos processos de trabalho.

\section{Considerações finais}

Erguida por meio de um longo processo de colonização e mantida sob a égide de uma modernização conservadora, que sobrevive às custas de uma democracia restrita e de períodos de transformismo, a sociedade brasileira, bem como sua estrutura educacional, evidencia sua filiação à concepção liberal burguesa de cidadania.

Ampliando o conceito de cidadania em uma perspectiva psicossocial, tendo como referência o fortalecimento dos movimentos sociais da década de 1980, nos foi possível reconhecer na concepção politécnica sua inscrição a um sentido coletivo e emancipatório de cidadania que denominamos 'cidadania como pertencimento'.

Com Guattari e Rolnik (1999), observamos que a subjetividade é fabricada por diferentes dispositivos (sociais, culturais, econômicos, políticos) presentes no mundo capitalístico. Nessa produção, o desejo de submissão do indivíduo pode intervir, estimulando-o a agir como simples receptor da subjetividade dominante em circulação nos espaços sociais. Por outro lado, na emergência dos chamados processos de singularização, o indivíduo pode, em sua existência particular, viver essa subjetividade de maneira criativa.

Como parte de um projeto emancipador que se distancia da ideologia liberal e de seus reflexos no campo do trabalho e da educação, afirmar a cidadania coletiva, resgatando o conceito em sua historicidade, torna-se um compromisso. Esse percurso deve ser inscrito por meio de processos que facilitem a promoção de sujeitos capazes de responder de forma autônoma ao seu processo de trabalho através de suas práticas sociais.

A necessidade dessa formação politécnica é fundamental, ainda, na tentativa de promover uma experiência educativa que, ao favorecer o resgate da singularidade dos futuros profissionais, promova mudanças não apenas nas práticas profissionais, mas nas estruturas sociais. Educar o cidadão e o ser humano emancipado significa contribuir para dar contorno às existências individuais desses atores e para uma nova forma de compreender a sociedade.

Pretender, na formação profissional, que o trabalho seja entendido como obra coletiva e como produtor de valores de uso para os trabalhadores - dentro das contradições da história - é considerar que o desenvolvimento integral das individualidades do sujeito-trabalhador é correlato ao seu investimento-cidadão em espaços genuinamente democráticos. 
Portanto, considerar a autonomia do trabalhador é condição de possibilidade para a elaboração de projetos coletivos. É nesse sentido que, longe do 'mal-estar na civilização' - descrito pela alegoria de Fellini - diante da coerção do poder sobre a autonomia, é possível recorrer à análise dos processos micro e macropolíticos do trabalho.

\section{Notas}

${ }^{1}$ Professora-pesquisadora da Escola Politécnica de Saúde Joaquim Venâncio, da Fundação Oswaldo Cruz. Mestre em Psicologia Clínica pela Pontifícia Universidade Católica (PUC-RJ) PUC/RJ. Doutoranda em Teoria do Estado e Direito Constitucional na Pontifícia Universidade Católica (PUC-RJ) < adrigeisler@fiocruz.br>

2 Para uma ampliação dessa análise, ver Fernandes (1981).

3 Ao que Sousa Santos (1999) denomina "fascismos pluralistas" (apartheid social, fascismo do Estado paralelo, fascismo contratual, fascismo da insegurança, "fascismo do capitalismo financeiro").

4 Para um maior aprofundamento sobre os questionamentos dessa escola "interessada", no dizer de Gramsci, pautada no trabalho produtivo, ver Nosella (1992).

${ }^{5}$ Por dimensão reflexiva, entende-se a complexidade formada pela dimensão intelectual e afetiva.

${ }^{6}$ A esse respeito, consultar a clássica distinção de Marx (1983) entre valor de uso e valor de troca.

\section{Referências}

ANTUNES, Ricardo. 1995. Adeus ao trabalho? Ensaio sobre as metamorfoses e a centralidade do mundo do trabalho. São Paulo: Cortez.

BAPTISTA, Luis. A. 1999. Os amoladores de facas. In: A cidade dos sábios e outros ensaios sobre a subjetividade e o cotidiano. Rio de Janeiro: Sumus.

BAUMAN, Zigmund. 1997. Ética pós-moderna. São Paulo: Paulus.

CAMPOS, Gastão Wagner de S. 2000. Um método de análise e co-gestão de coletivos. São Paulo: Hucitec.
CARVALHO, José Murilo de. 1987. Bestializados ou bilontras? In: Os bestializados. Rio de Janeiro: Companhia das Letras, p. 140-160. 1997. Interesses contra a cidadania. In: DAMATTA, Roberto (org.) Brasileiro: cidadão? São Paulo: Cultura Editores Associados.

CASTELO, José. 1994. Introdução. In: A ética e o espelho da cultura. Rio de Janeiro: Rocco.

COELHO JUNIOR, Nelson E. s.d. Intersubjetividade e isolamento pessoal nas te- 
orias fenomenológicas e psicanaliticas. São Paulo. (Mimeo).

COSTA, Jurandir F. 1994. A ética e o espelho da cultura. Rio de Janeiro: Rocco.

2000. A ética democrática e seus inimigos. In: O desafio ético. Rio de Janeiro: Garamond.

DAMATTA, Roberto. 1986. A casa e a rua: espaço, cidadania, mulher e morte no Brasil. Rio de Janeiro: Rocco.

. 1997. Um indivíduo sem rosto.

In: DAMATTA, Roberto (org.). Brasileiro: cidadão? São Paulo: Cultura Editores Associados.

2001. O que faz o Brasil, Brasil? Rio de Janeiro: Rocco.

DELUIZ, Neise. 1993. Formação do trabalhador: produtividade e cidadania. Rio de Janeiro: Shape.

1994. Formação do trabalhador em contexto de mudança tecnológica. Boletim Técnico do Senac, v. 20, n. 1, p. 1425.

ENRIQUEZ, Eugène. 1990. Da horda ao Estado: psicanálise do vínculo social. Rio de Janeiro: Zahar.

FERNANDES, Florestan. 1981. A revolução burguesa no Brasil: ensaio de interpretação sociológica. Rio de Janeiro: Zahar.

FOUCAULT, Michel. 1992. Microfísica do Poder. Rio de Janeiro: Graal.

FRIGOTTO, Gaudêncio; CIAVATTA, Maria. 2003. Educar o trabalhador cidadão produtivo ou o ser humano emancipado? Trabalho, Educação e Saúde, v. 1, n. 1, p. 45-60.

FRIGOTTO, Gaudêncio; CIAVATTA, Maria; RAMOS, Marise (orgs.). 2005. Ensino médio integrado: concepções e contradições. São Paulo: Cortez.

GOHN, Maria da Glória. 1995. História dos movimentos sociais e lutas sociais: a construção da cidadania dos brasileiros. São Paulo: Loyola.

GUATTARI, Félix. 1992. Caosmose: um novo paradigma estético. São Paulo: Ed. 34.

GUATTARI, Félix; ROLNIK, Sueli. 1999. Micropolitica: cartografias do desejo. Petrópolis: Vozes.

GUIRADO, Marlene. 1987. Psicologia institucional. São Paulo: EPU.
GURGEL, Cláudio. 2003. A gerência do pensamento: gestão contemporânea e consciência neoliberal. São Paulo: Cortez.

KOSIK, Karel. 1995. O século de Grete Samsa: sobre a possibilidade ou a impossibilidade do trágico no nosso tempo. Rio de Janeiro: Instituto de Letras, Universidade do Estado do Rio de Janeiro.

LAPASSADE, Georges. 1989. Grupos, organizações e instituições. Rio de Janeiro: Francisco Alves.

MARSHAL, Thomas H. 1988. Cidadania, classe social e status. Rio de Janeiro: Zahar.

MARQUES NETO, Agostinho R. 1994. Para a compreensão do sujeito jurídico: uma leitura transdisciplinar. In: Seleções jurídicas. Rio de Janeiro: Instituto dos Advogados Brasileiros.

MARX, Karl. 1983. O capital. São Paulo: Abril. MÉDICI, André Cezar; SILVA, Pedro Luiz B. 1993. Administração flexível: uma introdução às novas filosofias de gestão. Revista de Administração Pública, v. 26, n. 3, p. 26-36.

MILNER, Jean-Claude. s.d. Que é psicologia? In: COELHO, Eduardo P. (org.). Estruturalismo: antologia de textos teóricos. Tradução de Maria Eduarda Reis Colares et al. São Paulo: Martins Fontes.

NOSELLA, Paolo. 1992. A escola de Gramsci. Porto Alegre: Artes Médicas.

NUNES, Maria Fernanda R.; PEREIRA, Rita Marisa R. 1996. Buscando os mitos nas malhas da razão: uma conversa sobre educação e teoria crítica. In: KRAMER, Sonia; JOBIM E SOUZA, Solange (orgs.). Histórias de professores. São Paulo: Ática.

RAMOS, Marise. 2001. A pedagogia da competências: autonomia ou adaptação. São Paulo: Cortez.

SAWAIA, Bader. 1996. Dimensão ético-afetiva do adoecer da classe trabalhadora. In: LANE, Silvia; SAWAIA, Bader. Novas veredas da psicologia social. São Paulo: Brasiliense.

SADER, Eder S. 1988. Quando novos personagens entraram em cena: experiências, falas e lutas dos trabalhadores da grande São Paulo (1970-1980). Rio de Janeiro: Paz e Terra. 
SOUSA SANTOS, Boaventura de. 1999. Os riscos da destruição do contrato social. Folha de S. Paulo, 15 jun., Caderno Mais. 2001. A crítica da razão indolente contra o desperdício da experiência, v. 1. São Paulo: Cortez.

2002. Um discurso sobre as ciências. Porto: Afrontamento.

SANTOS, Wanderley Guilherme dos. 1979. Do laissez-faire repressivo à cidadania em recesso. In: Cidadania e justiça. Rio de Janeiro: Campus, p. 71-82.

SAVIANI, Dermeval. 2003. O choque teórico da politecnia. Trabalho, educação e saúde, v. 1, n. 1, p. 131-152.
VILHENA, Junia de; DIMENSTEIN, Magda; ZAMORA, Maria Helena. 2000. O trabalho do psicólogo com comunidades: cultura e formação profissional. Psicologia Clínica, v. 12, n. 1, p. 133-146.

VILHENA, Junia de. et al. 2001. Da cidade onde vivemos a uma clínica do território: lugar e produção de subjetividades. Rio de Janeiro. (Mimeo).

WACQUANT, Loïc. 2001. Os condenados da cidade: estudo sobre marginalidade avançada. Rio de Janeiro: Revan/Fase.

ZAMORA, Maria Helena. 2003. Conceito de comunidade: raízes e asas da psicologia social comunitária. Rio de Janeiro. (Mimeo) 